\title{
STATISTIKA DALAM PENGHITUNGAN KENDALI MUTU PEKERJAAN PEMBANGUNAN JALAN DINAS PEKERJAAN UMUM BINA MARGA JAWA TIMUR
}

\author{
Permadina Kanah Arieska \\ Dosen Statistika Universitas PGRI Adi Buana Surabaya
}

\begin{abstract}
Abstrak
Dinas Pekerjaan Umum Bina Marga Propinsi Jawa Timur memiliki tugas untuk senantiasa meningkatkan kualitas pelayanan jaringan jalan yang ada secara optimal, sehingga dapat memberikan kenyamanan dan keamanan bagi para pengguna jalan secara keseluruhan.Namun demikian, didalam pelaksanaaannya dilapangan masih cukup banyak ditemukan terjadinya kerusakan dini pada beberapa hasil kegiatan pelaksanaan pekerjaan, dalam hal ini pelaksanaan pekerjaan campuran aspal panas (hot mix) dibidang pemeliharaan jalan yang ada saat ini. Hal ini menunjukkan bahwa umur rencana konstruksi belum tercapai sebagaimana diharapkan, dan akan mempengaruhi tingkat pelayanan jalan bagi penggunanya.Dari 10 UPT (Unit Pelayanan Teknik) yang dijadikan sampel penelitian, secara deskriptif, terdapat beberapa titik uji yang berada diluar batas spesifikasi. Variabel yang diuji adalah ketebalan rata-rata, kepadatan (density) dan kadar aspal. Secara keseluruhan data yang berada diluar batas spesifikasi yaitu $\mathbf{9 . 7 3 \%}$ untuk ketebalan rata-rata $\mathbf{4 0 . 2 7 \%}$ untuk kepadatan (density) dan $\mathbf{6 . 0 4 \%}$ untuk kadar aspal.Keseluruhan data baik pada variable ketebalan, kepadatan dan kadar aspal, memiliki nilai yang bervariasi.
\end{abstract}

Kata kunci : Kendali Mutu, Kepadatan, Kadar Aspal, Ketebalan

\section{Pendahuluan}

Secara umum Dinas Pekerjaan Umum Bina Marga Jawa Timur mempunyai tugas utama melakukan pembinaan jaringan jalan di seluruh wilayah propinsi Jawa Timur, yakni pada ruas-ruas jalan Propinsi.

Terkait dengan tugas utamanya tersebut, Dinas Pekerjaan Umum Bina Marga Propinsi Jawa Timur juga berkewajiban untuk senantiasa meningkatkan kualitas pelayanan jaringan jalan yang ada secara optimal, sehingga dapat memberikan kenyamanan dan keamanan bagi para pengguna jalan secara keseluruhan.

Namun demikian, didalam pelaksanaaannya dilapangan masih cukup banyak ditemukan terjadinya kerusakan dini pada beberapa hasil kegiatan pelaksanaan pekerjaan, dalam hal ini pelaksanaan pekerjaan campuran aspal panas (hot mix) dibidang pemeliharaan jalan yang ada saat ini. Hal ini menunjukkan bahwa umur rencana konstruksi belum tercapai sebagaimana diharapkan, dan akan mempengaruhi tingkat pelayanan jalan bagi penggunanya.

Mengacu pada hal tersebut diatas, maka dirasa perlu untuk dilakukan kegiatan pengendalian pelaksanaan kegiatan pengendalian yang sistematis, yakni mencakup kegiatan evaluasi terhadap pencapaian mutu pelaksanaan pekerjaan yang berkualitas dan dapat mencapai umur rencana jalan yang diharapkan.

\section{Tinjauan Pustaka}

2.1 Statistika deskriptif

Statistika deskriptif adalah salah satu metode statistika yang berkaitan dengan pengumpulan, peringkasan, penyajian data, sehingga dapat memberikan informasi dan presentasi data.Dalam statistika deskriptif memang belum bisa mengambil keputusan terkait dengan data yang ada.Namun dapat dilakukan penggambaran secara deskriptif sehingga dapat diketahui gambaran awal tentang data. Harapannya statistika deskriptif akan dapat mendukung statistika inferensia. Statistika inferensia adalah metode statistika yang berkaitan dengan analisis data untuk peramalan atau untuk menarik kesimpulan.

\section{$2.2 \mathrm{Uji}$ t}

Uji t digunakan untuk mengetahui ada tidaknya hubungan atau pengaruh yang berarti (signifikan) antara variabel bebas secara parsial terhadap variabel terikat.

1. Penentuan hipotesis nihil dan hipotesis alternatif

$H o: b_{1}=0$, artinya tidak ada pengaruh yang signifikan antara variabel iklan televisi secara parsial terhadap variabel keputusan pembelian.

$H a: b_{1} \neq 0$, artinya ada pengaruh yang signifikan antara variabel iklan televisi terhadap variabel keputusan pembelian.

$\mathrm{H}_{0}: b_{2}=0$, artinya tidak ada pengaruh yang signifikan antara variabel iklan majalah secara parsial terhadap variabel keputusan pembelian 
a. Sampel dan Sumber Data

Jenis data yang digunakan dalam penelitian ini adalah data primer, yaitu data yang diperoleh secara langsung melalui pengujian secara langsung.Pada penelitian ini, banyaknya UPT yang akan diuji adalah 10 UPT dimana pada masing-masing UPT akan ditentukan satu atau lebih ruas jalan yang akan diambil sampelnya untuk diuji. Data yang diperoleh adalah survey langsung dilapangan berupa pengambilan benda uji (core drill) yang mencakup jenis-jenis data tentang ketebalan, kepadatan, dan kadar aspal. Kegiatan pengambilan benda uji pada ruas-ruas jalan yang telah ditentukan dilakukan oleh tenaga ahli surveyor dengan didampingi oleh tenaga ahli laboratorium, dengan menggunakan peralatan core drill dan sketch math. Tabel 3.3 menunjukkan jumlah sampel dan ruas jalan pada masing-masing UPT.

Tabel 3.3 menunjukkan jumlah sampel dan ruas jalan pada masing-masing UPT.

\begin{tabular}{|l|r|r|r|r|r|}
\hline \multirow{2}{*}{\multicolumn{1}{c|}{ UPT }} & \multicolumn{7}{|c|}{ RUAS JALAN } \\
\cline { 2 - 6 } & $\mathbf{1}$ & $\mathbf{2}$ & $\mathbf{3}$ & $\mathbf{4}$ & $\mathbf{5}$ \\
\hline BOJONEGORO & 14 & 17 & & & \\
\hline JEMBER & 12 & 12 & & & \\
\hline MALANG & 22 & 24 & & & \\
\hline MOJOKERTO & 8 & 6 & & & \\
\hline PROBOLINGGO & 12 & 12 & & & \\
\hline SURABAYA & 10 & 10 & 12 & 13 & 10 \\
\hline KEDIRI & 10 & 15 & & & \\
\hline MADIUN & 29 & & & & \\
\hline PACITAN & 18 & & & & \\
\hline TULUNGAGUNG & 19 & 13 & & & \\
\hline
\end{tabular}

\section{Analisa Data Dan Pembahasan}

Secara keseluruhan, dari 10 UPT yang dilakukan pengujian, terdapat nilai yang berada diluar batas spesifikasi.Pada Ketebalan rata-rata terdapat 29 data yang kurang dari 3.5. Total titik uji dari 10 UPT adalah sebanyak 298. Sehingga persentase pekerjaan yang tidak sesuai dengan spesifikasi yang ditentukan adalah:

$$
\begin{aligned}
& =\frac{\text { banyaknya data diluar batas spesifikasi }}{\text { data keseluruhan }} \\
& =\frac{29}{298} \times 100 \% \\
& =9.73 \%
\end{aligned}
$$

Jadi persentase pekerjaan yang sesuai dengan spesifikasi untuk variable ketebalan rata-rata adalah $100 \%-9.73 \%=90.27 \%$

Pada variabel kepadatan, jumlah data yang kurang dari batas bawah 98\% sebanyak 120. Sehingga persentase pekerjaan yang tidak sesuai dengan spesifikasi untuk variabel kepadatan (density) adalah:

$$
\begin{aligned}
& =\frac{\text { banyaknya data diluar batas spesifikasi }}{\text { data keseluruhan }} \\
& =\frac{120}{298} \times 100 \% \\
& =40.27 \%
\end{aligned}
$$

Jadi persentase pekerjaan yang sesuai dengan spesifikasi untuk variable kepadatan (density) adalah $100 \%-1.31 \%=59.73 \%$ 


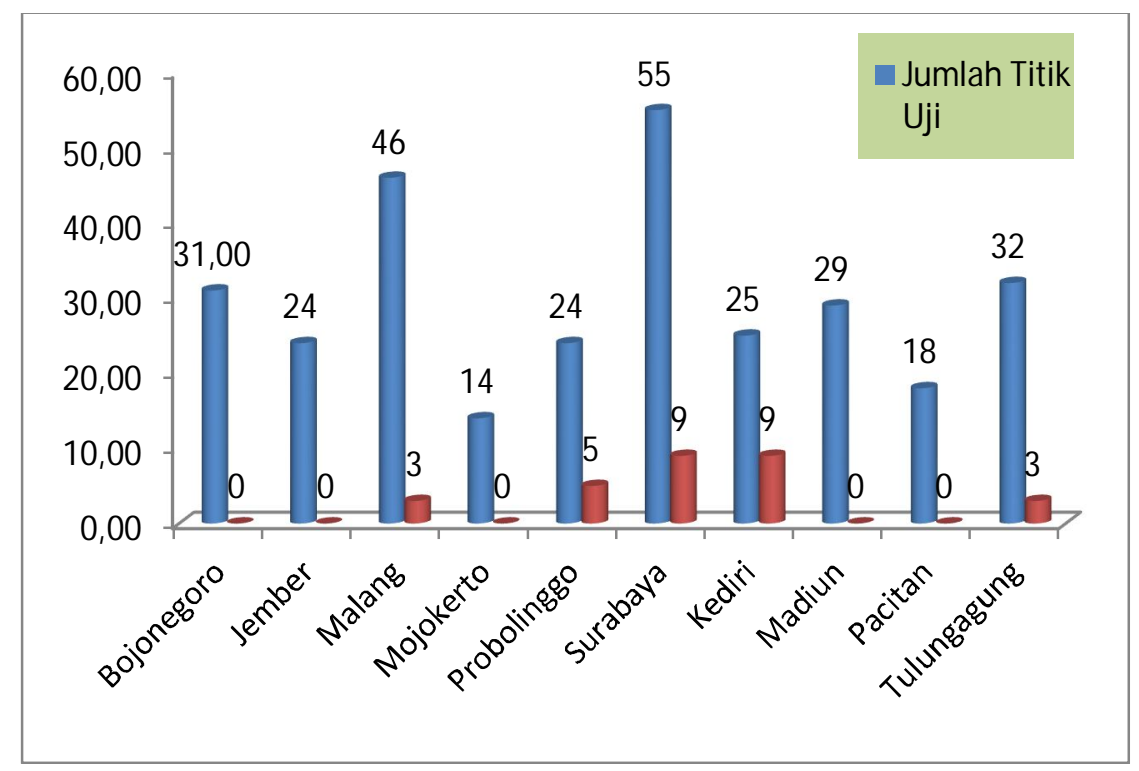

Gambar 4.1 Histogram Data Ketebalan Rata-Rata Kurang dari 3.5

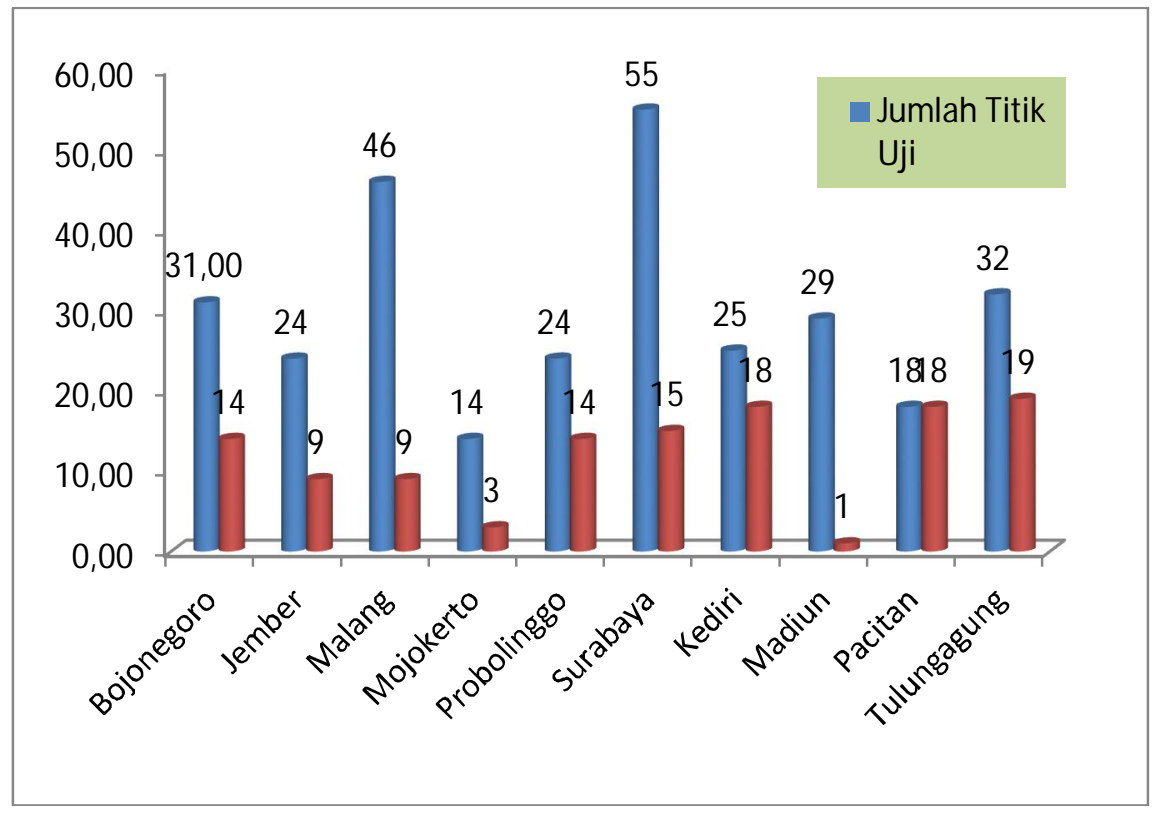

Grafik 4.2 Histogram Data Kepadatan (Density) kurang dari 98\%

Pada variabel Kadar aspal, terdapat 18 data yang berada diluar batas spesifikasi 4.3-7, yaitu 15 data berada diatas 7. Sehingga persentase pekerjaan yang sesuai dengan spesifikasi yang ditetapkan untuk kadar aspal adalah :

$$
\begin{aligned}
& =100 \%-\frac{\text { banyaknya data diluar batas spesifikasi }}{\text { data keseluruhan }} \\
& =100 \%-\left(\frac{18}{298} \times 100 \%\right) \\
& =100 \%-6.04 \% \\
& =93.96 \%
\end{aligned}
$$




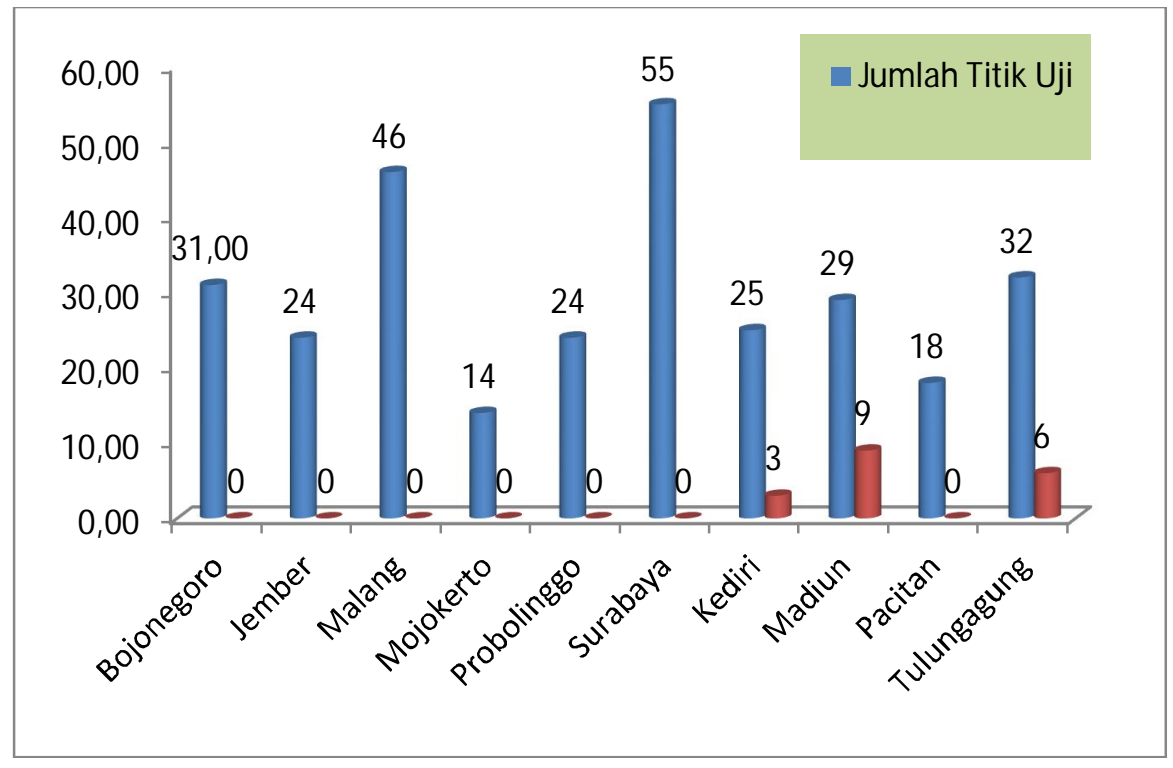

Grafik 4.3 Histogram Data Kadar Aspal diluar batas spesifikasi 4.3-7

a. Pengujian Data Sesuai dengan Standar Spesifikasi

Pada analisis deskriptif terdapat beberapa data yang berada diluar batas spesifikasi.Namun analisis deskriptif belum bisa digunakan untuk menarik kesimpulan bahwa UPT tersebut tidak sesuai dengan standar spesifikasi yang ditetapkan. Karena itu akan dilakukan pengujian untuk mengetahui apakah variable ketebalan, kepadatan dan kadar aspal sesuai dengan spesifikasi yang ditetapkan ataukah tidak. Tingkat keyakinan yang digunakan adalah $95 \%$.

Meskipun analisis deskriptif belum dapat digunakan untuk menarik kesimpulan, namun terdapat dugaan bahwa data memiliki nilai yang bervariasi.Terdapat data yang diduga sesuai dengan standar, ada juga yang berada dibawah standar dan ada pula yang diduga berada diatas standar. Hipotesis yang sesuai adalah sebagai berikut:

i. Ketebalan Rata-Rata

Pada data ketebalan rata-rata, hipotesis yang digunakan adalah:

$H_{0}=$ data ketebalan rata-rata pada UPT $\mathrm{X}=4$

$H_{1}=$ data ketebalan rata-rata pada UPT $\mathrm{X} \neq 4$

Tingkat kesalahan yang digunakan adalah 5\%, sehingga jika diperoleh p-value yang kurang dari $5 \%$, maka hipotesis awal $\left(H_{0}\right)$ ditolak.

\begin{tabular}{|c|c|c|c|c|c|c|c|c|}
\hline \multicolumn{9}{|c|}{$\begin{array}{l}\text { One-Sample T: Bojonegor } \\
\text { Test of } \mathrm{mu}=4 \text { vs not }=4\end{array}$} \\
\hline Variable & $\mathrm{N}$ & Mean & StDev & SE Mean & $95 \%$ & CI & $\mathrm{T}$ & $\mathrm{P}$ \\
\hline Bojonegoro & 31 & 4.297 & 0.597 & 0.107 & ( 4.078, & $4.516)$ & 2.77 & 0.010 \\
\hline Jember & 24 & 4.3300 & 0.4089 & 0.0835 & (4.1573, & $4.5027)$ & 3.95 & 0.001 \\
\hline Malang & 46 & 4.0015 & 0.3828 & 0.0564 & (3.8878, & $4.1152)$ & 0.03 & 0.979 \\
\hline Mojokerto & 14 & 4.966 & 0.945 & 0.252 & ( 4.421, & $5.512)$ & 3.83 & 0.002 \\
\hline Probolinggo & 24 & 3.9417 & 0.4739 & 0.0967 & (3.7416, & $4.1418)$ & -0.60 & 0.552 \\
\hline Surabaya & 55 & 4.923 & 1.002 & 0.135 & ( 4.652 , & 5.194) & 6.83 & 0.000 \\
\hline Kediri & 25 & 3.780 & 0.631 & 0.126 & ( 3.520 , & $4.040)$ & -1.74 & 0.094 \\
\hline Madiun & 29 & 4.3921 & 0.3629 & 0.0674 & (4.2540, & $4.5301)$ & 5.82 & 0.000 \\
\hline Pacitan & 18 & 4.607 & 0.451 & 0.106 & ( 4.383 , & $4.832)$ & 5.71 & 0.000 \\
\hline Tulungagung & 32 & 4.498 & 0.607 & 0.107 & ( 4.278 , & $4.717)$ & 4.63 & 0.000 \\
\hline
\end{tabular}


Gambar 4.4 menunjukkan bahwa p value yang memiliki nilai lebih dari 5\% hanya ada pada UPT Malang, Probolinggo dan Kediri, sehingga dapat dikatakan bahwa data ketebalan rata-ratanya sesuai dengan standar nominal 4. Sedangkan UPT yang lain akan dilakukan pengujian lebih lanjut. Hal ini dapat dilihat dari indikasi nilai Mean (rata-rata) pada UPT Malang, Probolinggo dan Kediri. Dari kolom Mean terlihat bahwa nilainya lebih besar dari 4. Karena itu akan dilakukan hipotesis lanjutan untuk menguji apakah data pada UPT tersebut memang lebih besar dari 4 ataukah tidak.

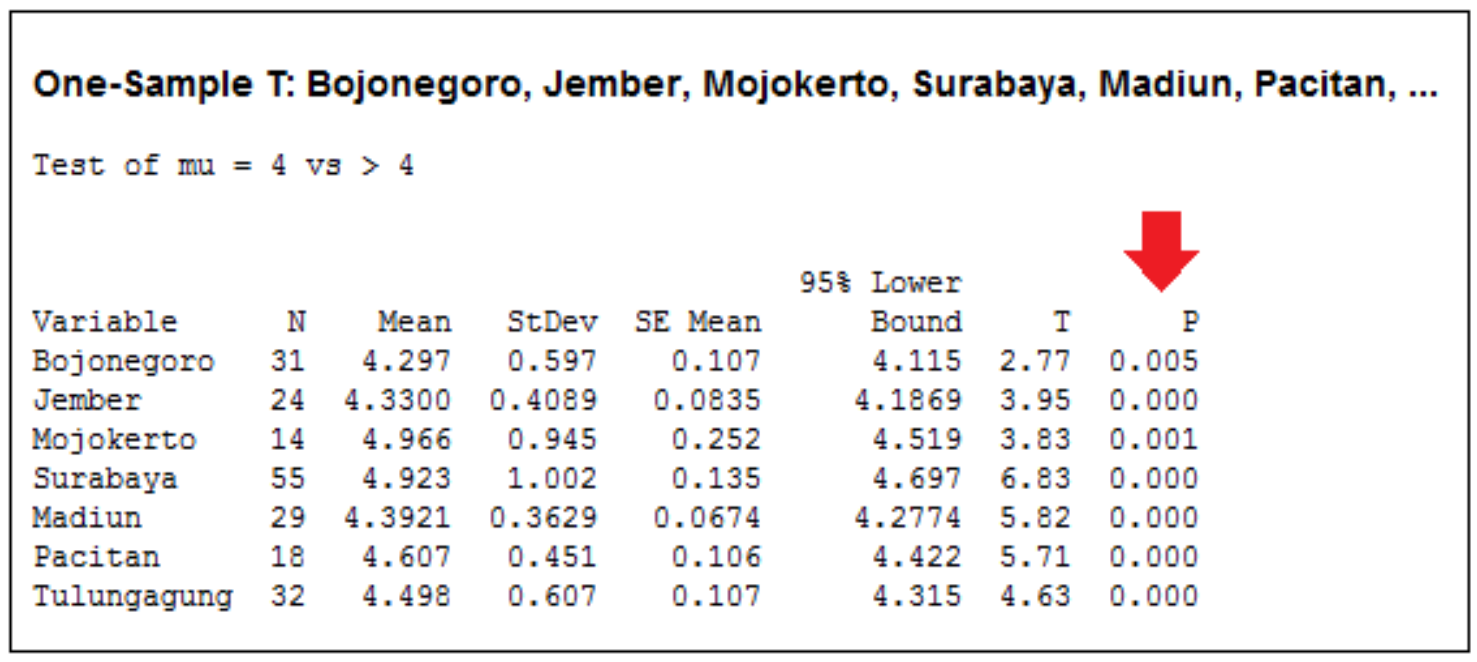

Gambar 4.5 Uji t Untuk Data Ketebalan Rata-Rata Lebih Besar 4

$H_{0}=$ data ketebalan rata-rata pada UPT $\mathrm{X}=4$

$H_{1}=$ data ketebalan rata-rata pada UPT $\mathrm{X}>4$

Terlihat pada tanda dengan panah merah nilainya kurang dari 5\%, sehingga tolak Hipotesis awal $\left(H_{0}\right)$ sehingga dapat disimpulkan memang data ketebalan pada UPT Bojonegoro,Jember,Mojokerto, Surabaya, Madiun, Pacitan dan Tulungagung nilainya lebih besar dari standar nominal 4.

ii. Kepadatan (Density)

Pada data kepadatan (Density), pengujian yang dilakukan adalah sebagai berikut:

$H_{0}=$ data kepadatan (density) pada UPT X $=98 \%$

$H_{1}=$ data kepadatan (density) pada UPT X $>98 \%$

Pada Gambar 4.66 terlihat bahwa hanya UPT Bojonegoro dan UPT Jember saja yang nilai $P$ nya lebih dari $5 \%$. Sehingga pada UPT ini dapat dikatakan bahwa data kepadatan pada UPT Bojonegoro dan Jember adalah 98\% sedangkan pada UPT yang lain bervariasi. Ada UPT yang nilainya kurang dari 98\% dan ada juga yang lebih dari $98 \%$. UPT yang memiliki nilai kepadatan lebih besar $98 \%$ adalah UPT yang ditunjukkan pada Gambar 4.7 sedangkan UPT yang memiliki nlai kepadatan lebih kecil ditunjukkan pada Gambar 4.8.

\begin{tabular}{|c|c|c|c|c|c|c|c|c|}
\hline \multicolumn{9}{|c|}{$\begin{array}{l}\text { One-Sample T: Bojonegoro, } \\
\text { Test of mu }=98 \text { vs not }=98\end{array}$} \\
\hline Variable & $\mathrm{N}$ & Mean & StDev & SE Mean & $95 \frac{8}{5}$ & $\mathrm{CI}$ & $\mathrm{I}$ & $P$ \\
\hline Bojonegoro & 31 & 98.199 & 1.322 & 0.237 & $(97.714$, & $98.684)$ & 0.84 & 0.408 \\
\hline Jember & 24 & 99.425 & 3.823 & 0.780 & (97.811, & 101.039) & 1.83 & 0.081 \\
\hline Malang & 46 & 100.230 & 2.491 & 0.367 & (99.491, & $100.970)$ & 6.07 & 0.000 \\
\hline Mojokerto & 14 & 98.863 & 1.424 & 0.381 & (98.041, & $99.685)$ & 2.27 & 0.041 \\
\hline Probolinggo & 24 & 95.988 & 4.281 & 0.874 & (94.180, & $97.796)$ & -2.30 & 0.031 \\
\hline Surabaya & 55 & 99.409 & 1.949 & 0.263 & (98.882, & $99.936)$ & 5.36 & 0.000 \\
\hline Kediri & 25 & 96.522 & 1.434 & 0.287 & (95.930, & $97.114)$ & -5.15 & 0.000 \\
\hline Madiun & 29 & 101.060 & 3.894 & 0.723 & (99.579, & $102.541)$ & 4.23 & 0.000 \\
\hline Pacitan & 18 & 94.018 & 2.018 & 0.476 & $(93.014$, & $95.021)$ & -8.37 & 0.000 \\
\hline Tulungagung & 32 & 97.358 & 0.988 & 0.175 & $(97.002$, & $97.714)$ & -3.68 & 0.001 \\
\hline
\end{tabular}

Gambar 4.6 Uji t Untuk Data Kepadatan (Density) 


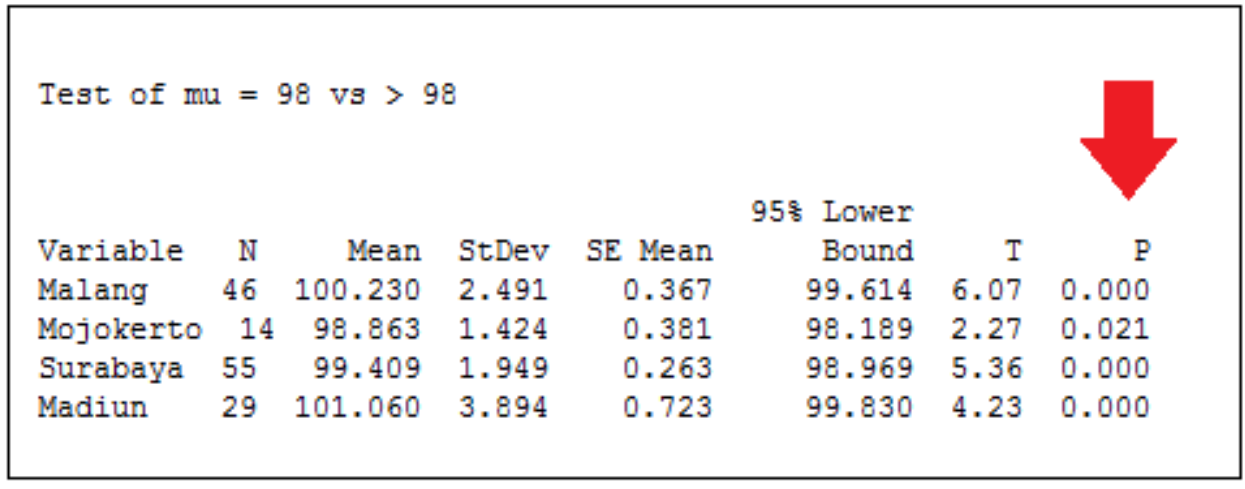

Gambar 4.7 Uji t Untuk Data Kepadatan (Density) lebih besar dari 98\%

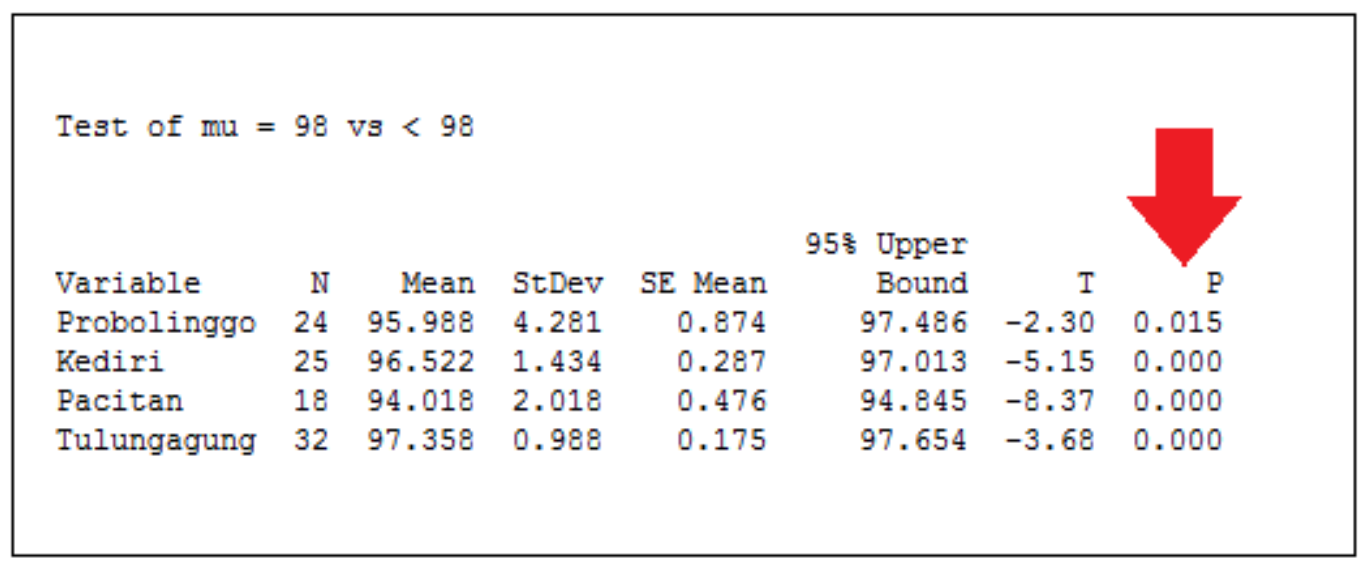

Gambar 4.8 Uji t Untuk Data Kepadatan (Density) lebih kecil dari 98\%

iii. Kadar Aspal

Pada data kadar aspal, hanya UPT Jember yang dapat dikatakan nilai kadar aspalnya samadengan 6 . Sedangkan nilai kadar aspal pada UPT yang lain ada yang memiliki nilai kurang dari 6 dan ada pula yang lebih besar dari 6 .

\begin{tabular}{|c|c|c|c|c|c|c|c|c|}
\hline Variable & N & Mean & StDev & SE Mean & $95 \%$ & CI & T & P \\
\hline Bojonegoro & 31 & 5.8542 & 0.1277 & 0.0229 & (5.8074, & $5.9010)$ & -6.36 & 0.000 \\
\hline Jember & 24 & 6.0263 & 0.2502 & 0.0511 & (5.9206, & $6.1319)$ & 0.51 & 0.612 \\
\hline Malang & 46 & 5.9315 & 0.1116 & 0.0164 & (5.8984, & $5.9646)$ & -4.16 & 0.000 \\
\hline Mojokerto & 14 & 5.8629 & 0.0522 & 0.0140 & (5.8327, & $5.8930)$ & -9.82 & 0.000 \\
\hline Probolinggo & 24 & 5.9154 & 0.0813 & 0.0166 & (5.8811, & $5.9497)$ & -5.10 & 0.000 \\
\hline Surabaya & 55 & 5.9156 & 0.2012 & 0.0271 & (5.8613, & $5.9700)$ & -3.11 & 0.003 \\
\hline Kediri & 25 & 6.2136 & 0.4778 & 0.0956 & (6.0164, & $6.4108)$ & 2.24 & 0.035 \\
\hline Madiun & 29 & 6.532 & 0.653 & 0.121 & ( 6.283 , & $6.780)$ & 4.39 & 0.000 \\
\hline Pacitan & 18 & 5.9689 & 0.0587 & 0.0138 & (5.9397, & 5.9981) & -2.25 & 0.038 \\
\hline Tulungagung & 32 & 6.319 & 0.573 & 0.101 & ( 6.113, & $6.526)$ & 3.15 & 0.004 \\
\hline
\end{tabular}




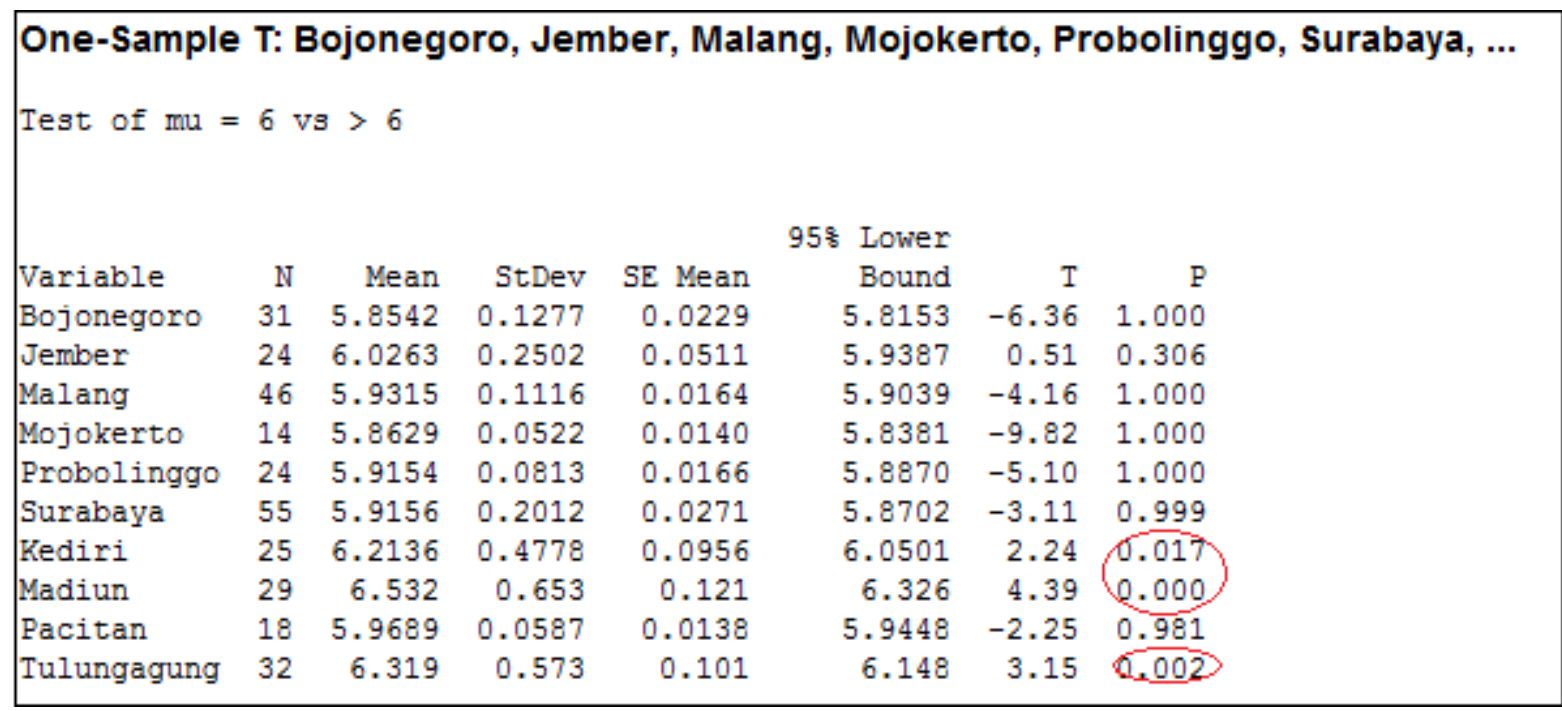

Gambar 4.10 Uji t Untuk Kadar Aspal lebih besar 6

Dari Gambar 4.10 dan 4.11 terlihat bahwa UPT yang nilai kadar aspalnya lebih dari 6 adalah Kediri, Madiun, Tulungagung dengan rata-rata berkisar antara 6.2-6.5 dan UPT yang nilai kadar aspalnya kurang dari 6 adalah Bojonegoro, Malang, Mojokerto, Probolinggo, Surabaya dan Pacitan dengan rata-ratanya adalah 5.8.

\begin{tabular}{|c|c|c|c|c|c|c|c|}
\hline \multicolumn{8}{|c|}{ One-Sample T: Bojonegoro, Jember, Malang, Mojokerto, Probolinggo, Surabaya, ... } \\
\hline Variable & N & Mean & StDev & SE Mean & $\begin{array}{l}95 \% \text { Upper } \\
\text { Bound }\end{array}$ & $\mathrm{P}$ & \\
\hline Bojonegoro & 31 & 5.8542 & 0.1277 & 0.0229 & 5.8931 & -6.360 .000 & \\
\hline Jember & 24 & 6.0263 & 0.2502 & 0.0511 & 6.1138 & $0.51 \quad 0.694$ & \\
\hline Malang & 46 & 5.9315 & 0.1116 & 0.0164 & 5.9591 & $-4.16,0.000$ & \\
\hline Mojokerto & 14 & 5.8629 & 0.0522 & 0.0140 & 5.8876 & $-9.82(0.000$ & \\
\hline Probolinggo & 24 & 5.9154 & 0.0813 & 0.0166 & 5.9439 & 0.000 & \\
\hline Surabaya & 55 & 5.9156 & 0.2012 & 0.0271 & 5.9610 & 0.001 & \\
\hline Kediri & 25 & 6.2136 & 0.4778 & 0.0956 & 6.3771 & 0.983 & \\
\hline Madiun & 29 & 6.532 & 0.653 & 0.121 & 6.738 & $4.39 \quad 1.000$ & \\
\hline Pacitan & 18 & 5.9689 & 0.0587 & 0.0138 & 5.9930 & -2.250 .019 & \\
\hline Tulungagung & 32 & 6.319 & 0.573 & 0.101 & 6.491 & $3.15 \quad 0.998$ & \\
\hline
\end{tabular}

Gambar 4.11 Uji t Untuk Kadar Aspal lebih kecil 6

Tabel 4.1 Rangkuman Uji t

\begin{tabular}{|l|c|c|c|c|c|c|c|c|c|}
\hline \multirow{2}{*}{\multicolumn{1}{c|}{ UPT }} & \multicolumn{3}{|c|}{ Ketebalan } & \multicolumn{4}{c|}{ Kepadatan } & \multicolumn{3}{c|}{ Kadar Aspal } \\
\hline & $<\mathbf{4}$ & $\mathbf{4}$ & $\mathbf{> 4}$ & $\mathbf{< 9 8}$ & $\mathbf{9 8 \%}$ & $\mathbf{> 9 8 \%}$ & $\mathbf{< 6}$ & $\mathbf{6}$ & $\mathbf{> 6}$ \\
\hline BOJONEGORO & & & $\sqrt{ }$ & & $\sqrt{ }$ & & $\sqrt{ }$ & & \\
\hline JEMBER & & & $\sqrt{ }$ & & $\sqrt{ }$ & & & $\sqrt{ }$ & \\
\hline MALANG & & $\sqrt{ }$ & & & & $\sqrt{ }$ & $\sqrt{ }$ & & \\
\hline MOJOKERTO & & & $\sqrt{ }$ & & & $\sqrt{ }$ & $\sqrt{ }$ & & \\
\hline PROBOLINGGO & & $\sqrt{ }$ & & $\sqrt{ }$ & & & $\sqrt{ }$ & & \\
\hline SURABAYA & & & $\sqrt{ }$ & & & $\sqrt{ }$ & $\sqrt{ }$ & & \\
\hline KEDIRI & & $\sqrt{ }$ & & $\sqrt{ }$ & & & & & $\sqrt{ }$ \\
\hline MADIUN & & & $\sqrt{ }$ & & & $\sqrt{ }$ & & & $\sqrt{ }$ \\
\hline PACITAN & & & $\sqrt{ }$ & $\sqrt{ }$ & & & $\sqrt{ }$ & & \\
\hline TULUNGAGUNG & & & $\sqrt{ }$ & $\sqrt{ }$ & & & $\sqrt{ }$ & \\
\hline
\end{tabular}




\section{Kesimpulan}

Dari analisis yang dilakukan diperoleh kesimpulan sebagai berikut:

a. Secara deskriptif, terdapat beberapa data yang diluar batas spesifikasi yaitu $\mathbf{9 . 7 3 \%}$ untuk ketebalan rata-rata40.27\% untuk kepadatan (density) dan 6.04\% untuk kadar aspal.

b. Keseluruhan data baik pada variable ketebalan, kepadatan dan kadar aspal, memiliki nilai yang bervariasi. Berikut hasilnya:

1. Ketebalan Rata-Rata sesuai standar nominal 4 :Malang, Probolinggo dan Kediri.

2. Ketebalan Rata-Rata lebih dari 4 : Bojonegoro, Jember, Mojokerto, Surabaya, Madiun, Pacitan dan Tulungagung

3. Kepadatan sama dengan 98\% : Bojonegoro dan Jember.

4. Kepadatan kurang dari $98 \%$ : Probolinggo, Kediri, Pacitan dan Tulungagung

5. Kepadatan lebih dari $98 \%$ : Malang, Mojokerto, Surabaya dan Madiun

6. Kadar Aspal sama dengan 6: Jember

7. Kadar Aspal kurang dari 6 : Bojonegoro, Malang, Mojokerto, Surabaya, Probolinggo, Pacitan dan Tulungagung

8. Kadar Aspal lebih dari 6 : Kediri dan Madiun

\section{Daftar Pustaka}

Bhattacharyya, G.K dan Jhonson, R.A., 1997.Statistical Concept and Methods.Jhon Wiley \& Sons, Inc. Montgomery, Douglas C., 1991. Design and Analysis of Experiments.Jhon Wiley \& Sons, Inc.

Iriawan, Nur dan Septin. 2006. Mengolah Data Statistik dengan Mudah Menggunakan Minitab 14. Penerbit Andi Yogyakarta. 
14 | Permadina Kanah Arieska 